九州大学学術情報リポジトリ

Kyushu University Institutional Repository

\title{
Boiling Phenomenon of Graphene Nano-Coating Wick Heat Pipe
}

\section{Wayan Nata Septiadi}

Department of Mechanical Engineering Udayana University

\section{Astawa, Ketut}

Department of Mechanical Engineering Udayana University

I Gusti Ayu Pristha Arvikadewi

Heat Transfer Laboratory Department of Mechanical Engineering Udayana University

Febraldo, David

Heat Transfer Laboratory Department of Mechanical Engineering Udayana University

他

https://doi.org/10.5109/4055236

出版情報：Evergreen. 7 (2)，pp.297-302，2020-06. 九州大学グリーンテクノロジー研究教育センター バージョン：

権利関係 : 


\title{
Boiling Phenomenon of Graphene Nano-Coating Wick Heat Pipe
}

\author{
Wayan Nata Septiadi1,2,*, Ketut Astawa, ${ }^{1,2}$, I Gusti Ayu Pristha Arvikadewi ${ }^{2,3}$, \\ David Febraldo ${ }^{2,3}$, Gerardo Janitra Puriadi Putra ${ }^{2,3}$ \\ ${ }^{1}$ Department of Mechanical Engineering Udayana University, Kampus UNUD Bukit Jimbaran, Badung-Bali \\ ${ }^{2}$ Heat Transfer Laboratory Department of Mechanical Engineering Udayana University. \\ ${ }^{3}$ Undergraduate students of Mechanical Engineering Study Program Udayana University.
}

*Author to whom correspondence should be addressed:

E-mail: wayan.nata@gmail.com,wayan.nata@unud.ac.id

(Received November 7, 2019; Revised May 7, 2020; accepted May 21, 2020).

\begin{abstract}
Experiment of nano-capillary boiling phenomenon of graphene nano-based heat pipe on water as working fluids have been carried out. The coating process is carried out by performing an electrophoretic deposition process using graphene nanofluid. Graphene nanofluid was made by heating and stirring for 15 minutes in a solution consisting of graphene and distilled water with a fraction volume of $1 \%$, then followed by an EPD process by dipping a copper pipe into a nanofluid which was given a platinum anode and 23 volt of electricity for 15 seconds. Boiling phenomena can be observed from the results of data retrieval through high-speed visualization cameras while observing thermal performance through temperature data retrieval. Based on the results obtained, the nanocoated heat pipe thermal performance is better than the uncoated heat pipe. The nanocoated heat pipe could handle higher heat flux as shown by the boiling curve at lower temperature difference between heat pipe surface and the saturated water, higher heat transfer coefficient about 215\% than the uncoated heat pipe which indicates that the heat transfer phenomena occurred in nanocoated heat pipe is better than uncoated heat pipe. The bubble diameter that formed in the boiling process of nanocoated heat pipe is smaller and released faster than the uncoated heat pipe.
\end{abstract}

Keywords: Nano coating; Pool Boiling; Wick Heat Pipe

\section{Introduction}

Heat pipe is a passive two-phase heat exchanger technology, where the heat pipe itself is a structure with high thermal conductivity that allows heat transportation by maintaining a uniform temperature difference along the part that is heated and cooled. Thermal performance of heat pipes can be determined from the value of heat resistance, when heat resistance is small, then the rate of displacement if it increases so does vice versa ${ }^{1,2,3)}$. Factors that can influence the value of heat resistance between them are working fluid as a medium for conducting heat and wick as a medium in the circulation of working fluid and nucleic formation in the evaporator ${ }^{3,4,5)}$. Wick is a liquid fluid media circulating with the principle of capillarity ${ }^{6,7)}$. Capillary on wick can be formed because of the existence of cavities, so that wick is also called porous media $^{8,9)}$ Porous media on wick can be made from materials that have characteristics such as fluid surface tension with porous media, permeability and porosity where all three of these are important factors in nucleic formation. In the boiling pool, nucleic shapes and movements that tend to be dynamic in aquades are significantly affected by the surface coated with nanoparticles $^{10,11,12)}$.

Nanocoating application of heat pipe evaporators and thermosyphons is considered as means to increase the heat transfer ${ }^{13,14)}$. It is also based on the charge volume and concentration of nanoparticles that could reduce the thermal resistance and increase thermal efficiency of the heat pipe significantly. Heat pipe with nanocoated wick could also reduce thermal resistance and reduce the evaporator and condenser wall temperature ${ }^{15,16,17)}$.

The wick that based on nano-coating could be made from graphene, it is one of the material that can be used for nano-coating processes due to the high thermal conductivity of graphene and not soluble in water or organic solvents. To synthesize nanofluid in the graphene nano-coating process is carried out by mixing particles graphene with water, then stirred and given heat treatment into nanofluid graphene. This nanofluid is used as a component of the main nano-coating process by dipping a 
wick material on graphene nanofluid and given heat treatment ${ }^{18)}$.

\section{Theory Analysis and Methodology}

\subsection{Pool Boiling}

The boiling curve and the temperature change curve over time in this study are produced to study the heat transfer character in a narrow gap. The definition of boiling regime has been produced by Nukiyama based on experiments on pool boilings, the boiling curve is shown in Figure 1 A-B regime: heat is transferred through singlephase free convection. Q heat flux in this area is (sTs 5/4). $\mathrm{B}-\mathrm{C}$ regime: water near the hot wall is superheated and tends to evaporate, bubbles are formed in locations where there are strokes or small holes around the hot wall surface. The bubbles transport latent heat of evaporation and also increase convection heat transfer. The boiling mechanism in this area is called nucleate boiling and is shown only with a very high heat transfer rate at small temperature differences. In the boiling region, flux $\mathrm{q}$ is a function $(\Delta \mathrm{Ts}) \mathrm{n}$ in general, the values range from 2 to 5 .

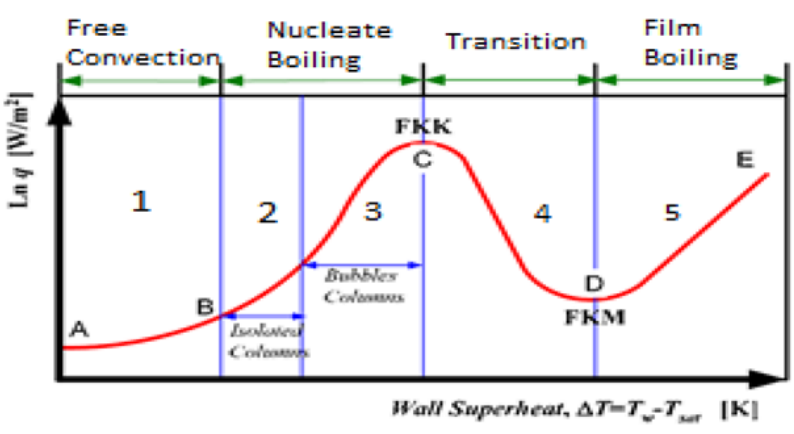

Fig. 1: The regime curves boiling in the pool boiling

The heat transfer coefficient in the boiling curve is expressed as in figure 1 as follows ${ }^{19,20}$. The amount of heat transfer coefficient is obtained from calculations using equation (1):

$$
h=\frac{q}{\Delta T_{S}}=\frac{P / \pi D L}{\left(T_{W}-T_{S a t}\right)}=\frac{(V \times I) / \pi D L}{\left(T_{W}-T_{S a t}\right)}
$$

which in this case, the Tsat is maintained at $90{ }^{\circ} \mathrm{C}$ as the saturated water temperature.

\subsection{Nano Graphene}

Graphene is the thinnest compound known to humans in one thick atom, the lightest material known as 1 square meter weighing about 0.77 milligrams, the strongest compound found with a strength between 100-300 times stronger than steel and with a tensile stiffness of $150,000,000 \mathrm{psi}$, the best heat conductor at room temperature (at $(4.84 \pm 0.44) \times 103$ to $(5.30 \pm 0.48) \times 103$
$\left.\mathrm{W} \cdot \mathrm{m}^{-1} \cdot \mathrm{K}^{-1}\right)^{21)}$ and also the best known electrical conductor, from studies that have shown electron mobility at values more than $200,000 \mathrm{~cm}^{2} \mathrm{~V}^{-1} \mathrm{~s}^{-1}$. This nanoplatelet consists of graphenes that are 1 to 15 nanometers thick, with diameters ranging from sub-micrometers to 100 micrometers ${ }^{22)}$. These features show that interplant distance in chipped graphite is similar to parent graphite, but the size of the stack (from the graphene layer) is small $23,24,25)$

\subsection{Experiment Methodology and Procedure Graphene Nanofluid Preparation}

Nano Coating Graphene is a coating process using graphene nanofluid. Whereafter graphene nanofluid was obtained, coating was carried out on the heat pipe. Graphene nanofluid was made by heating and stirring for 15 minutes in a solution consisting of graphene and distilled water with a volume fraction of $1 \%$. The following figure is the scheme of making graphene nanofluid ${ }^{17)}$

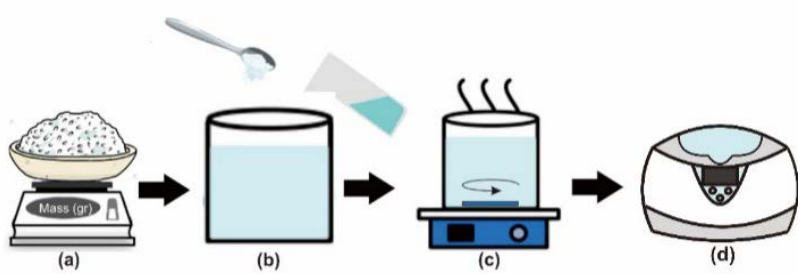

Fig 2. Graphene nanofluid synthesis schematic

\section{Experimental Set-Up}

Figure 2 shows the pool boiling test scheme, in this test used commercial electric heaters with a maximum power of $300 \mathrm{~W}$ and a maximum voltage of 170 volts. This heater is connected to an adjustable DC power supply. The dimension of the electric heater is $150 \mathrm{~mm}$ long and $6 \mathrm{~mm}$ in diameter made of stainless steel. Before the main heater is used, the boiling process is assisted with additional heating. Temperature measurement is done by using type $\mathrm{K}$ thermocouples with $0.02{ }^{\circ} \mathrm{C}$ temperature accuracy. It is placed at two points, one point on the surface of the heater and one point on the fluid. Thermocouples are connected with NI 9201 data acquisition system which sends analog signals and will be converted into digital signals on the computer through LabView software. The software is programmed to record data per second. The condenser part is connected to a circulating thermostatic bath which operates at $25^{\circ} \mathrm{C}$. The tube used in this boiling test is made of pyrex glass with a thickness of $6 \mathrm{~mm}$, a height of 200 $\mathrm{mm}$, an outer diameter of $115 \mathrm{~mm}$ and an inner diameter of the tube $103 \mathrm{~mm}$. the bottom part is made of copper which also functions as a heating stand. 


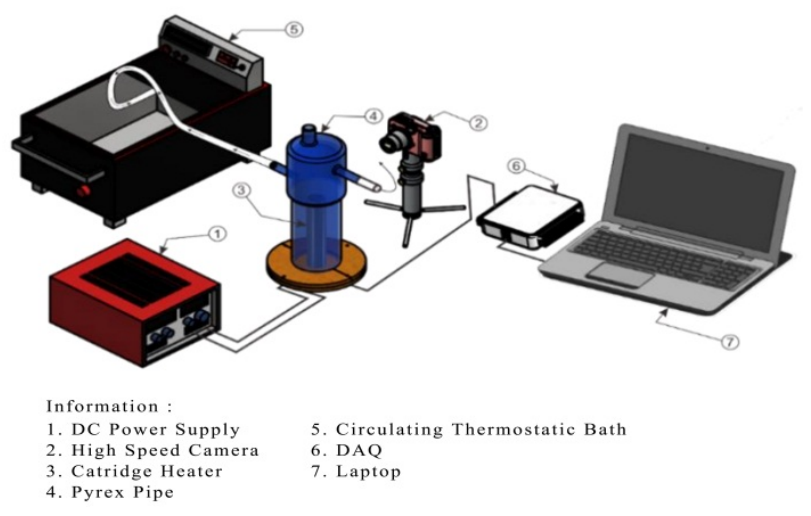

Fig. 3 Pool boiling experimental set-up

\section{Result and Discussion}

Based on Scanning Electron Microscope (SEM) microscopic analysis result, it can be seen the microstructure of the graphene nano-coated heat pipe as shown in Figure 4. The results were obtained by performing an electrophoretic deposition process using graphene nanofluid. Graphene nanofluid was made by heating and stirring for 15 minutes in a solution consisting of graphene and distilled water with a volume fraction of $1 \%$, then followed by an EPD process by dipping a copper pipe into a nanofluid which had been given a platinum anode and 23 volts of electricity during 15 seconds. The microscopic analysis was carried out with 3500, 10,000 and 25,000 times magnification, having a thickness of $198 \mu \mathrm{m}$. Based on the analysis of Image-J software, the average pore diameter is $2,189 \mu \mathrm{m}$ with a standard deviation of 1,664 .

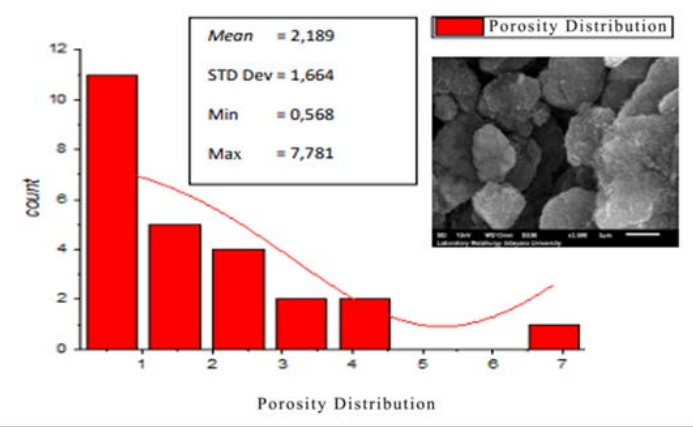

Fig. 4 Porosity of grapheme nano-coating wick

Based on observations, it can be observed that voltage regulator voltage increases also raise the temperature until it reaches a steady-state, starting from 70 volts to 150 volts. The temperature difference between surface temperature and fluid temperature is also seen to be greater in noncoated heat pipes compared to graphene nano-coated heat pipes. Changes in heat flux to heater temperature difference and fluid temperature between the surface of the non-coated heat pipe and graphene nano-coated heat pipe can be seen in Figure 5. Based on the graph, it can be seen that nano heat transfer performance of graphene heat pipe coating is better than non-coated heat pipe based on the increase in heat flux and a decrease in $\Delta \mathrm{T}$ which starts when the heat flux is above $10 \mathrm{~kW} / \mathrm{m}^{2}$. Increasing $\Delta \mathrm{T}$ graphene heat pipe after heat flux above $20 \mathrm{~kW} / \mathrm{m}^{2}$ is due to the condensation process that occurs.

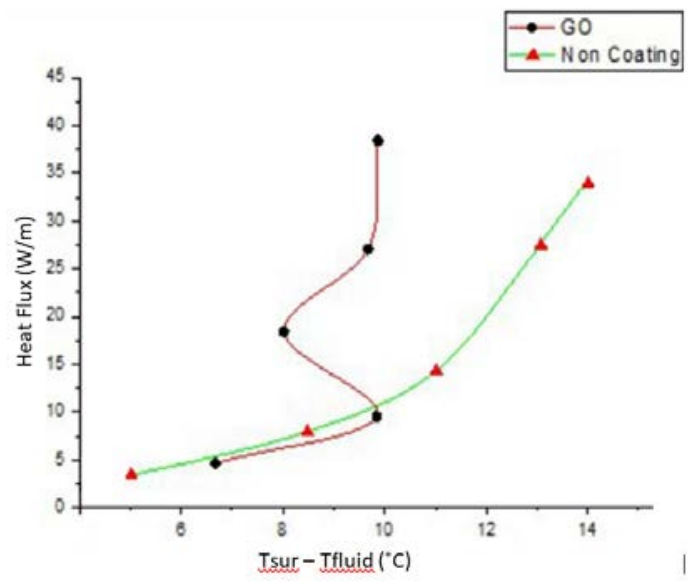

Fig. 5 Heat flux distribution

Based on Figure 6, graphene nano-coated heat pipe have a better heat transfer coefficient than non-coated heat pipes which starts when heat fluxes are above $10 \mathrm{~kW} / \mathrm{m}^{2}$. The data stated that heat transfer coefficient of graphene nano-coated heat pipes is $215 \%$ better from non-coated heat pipe comparing the two heat transfer coefficients that have the highest difference.

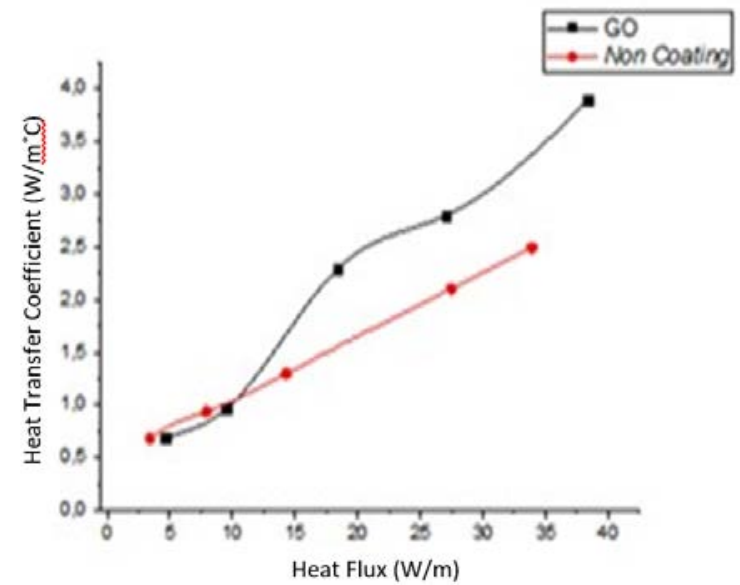

Fig. 6 Heat transfer coefficient distribution

The bubble formation process in pool boiling phenomena from non-coated heat pipe and graphene nano-coated heat pipe can be seen in Figure 7 and Figure 8. Based on figures 7 and 8 , it can be seen that the higher the voltage applied, the smaller the bubble will be and the faster it will release from the other bubbles. This bubble phenomena occurred because the nano porosity formed by the nanocoating on the surface. Bubbles appear when the voltage is 70 volts, wherein this condition the bubbles tend to be difficult to remove from the heating source, this changes with the bubble conditions formed which release faster and the bubbles formed are separated from the other bubbles when the voltage is increased to 150 volts. Bubble diameter size can be observed with the ImageJ application, 
this makes it possible to analyze the distribution of bubble distribution as shown in figure 9 and figure 10.

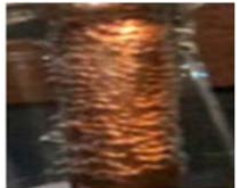

70 volt

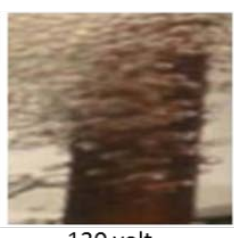

130 volt

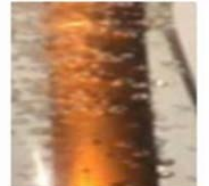

90 volt

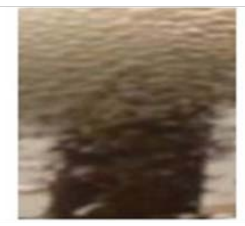

150 volt
Fig. 7 Bubble phenomenon of pool boiling non-coated heat

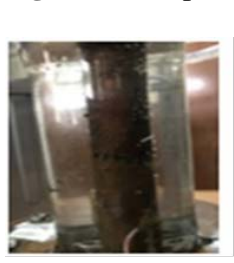

70 volt

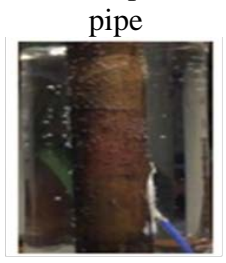

90 volt

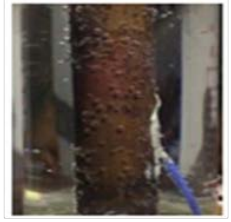

110 volt

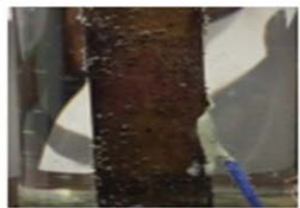

130 volt

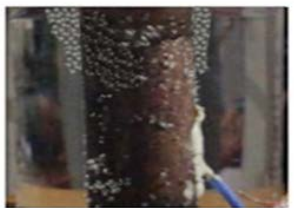

150 volt
Fig. 8 Bubble phenomenon of pool boiling graphene nanocoated wick heat pipe
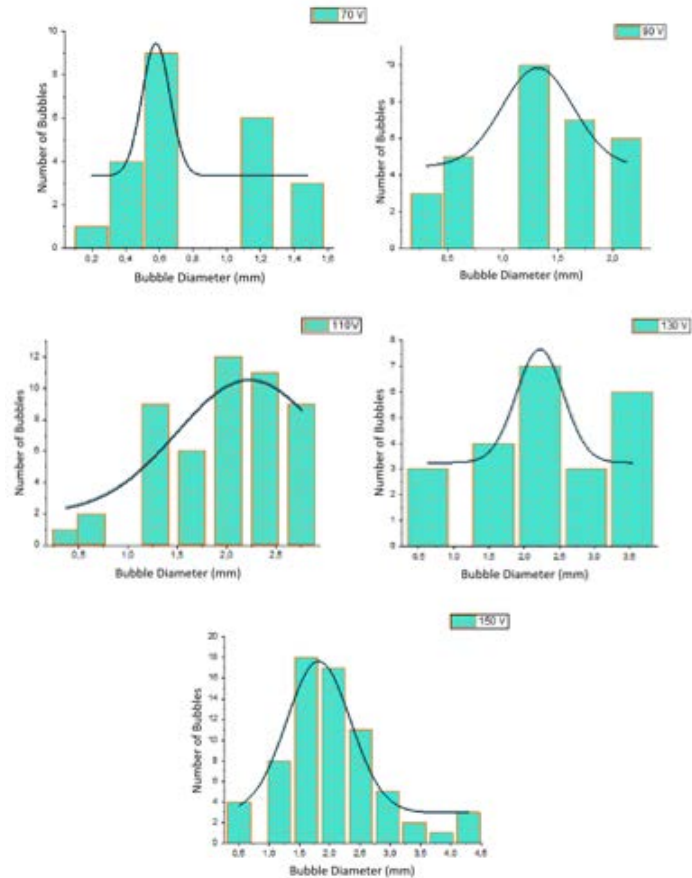

Fig. 9 Uncoated heat pipe bubble distribution graph
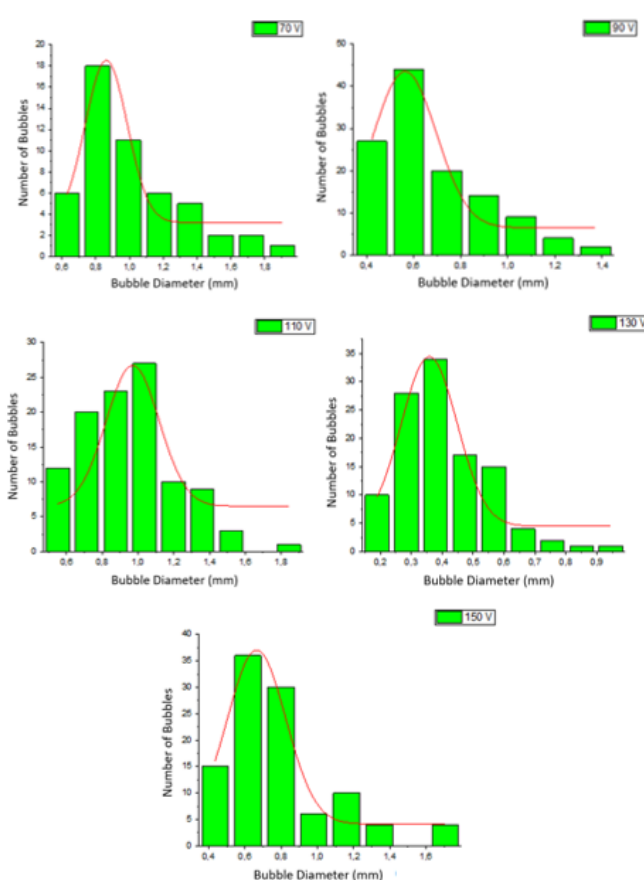

Fig. 10 Graphene coated heat pipe bubble distribution graph

Based on the graph shown in figure 10, the distribution of bubble distribution can be seen that with the ratio of the number of bubbles with a diameter smaller than the 70volt voltage it continues to increase to a voltage of 150 volts. The distribution graph also shows the bubble size of the graphene nano-coated heat pipe smaller than that of the non-coated heat pipe which indicates that the bubble is faster apart from the graphene nano-coated heat pipe. It is possible that this process is altered as graphene nanoparticle surface treatment to produce a greater number of large cavities distribution for smaller porosity. As a result, the boiling curve of the graphene nanocoating displays a lower wall superheat under the same load as compared to the non-coated wick. The boiling curve on the nano-coated surface displays a smaller bubble to the boiling curves on the graphene nano-coated surfaces. On the other hand, the boiling curve of the nano-coated wick displays a higher value of the non-coated heat pipe.

\section{Conclusion}

Based on the results obtained, the nanocoated heat pipe thermal performance is better than the uncoated heat pipe. The nanocoated heat pipe could handle higher heat flux as shown by the boiling curve at lower temperature difference between heat pipe surface and the saturated water, also a higher heat transfer coefficient about $215 \%$ than the uncoated heat pipe which indicates that the heat transfer phenomena occurred in nanocoated heat pipe is better than uncoated heat pipe. The bubble diameter that formed in the boiling process of nanocoated heat pipe is smaller and released faster than the uncoated heat pipe because of the nano porosity formed by the nanocoating layer. 


\section{Acknowledgments}

Thank you to the Ministry of Technology and Higher Education and the Udayana Institute for Research and Community Service for financial support through the 2019 Penelitian Unggulan Udayana (PUU) scheme with Contract Number 551.78/UN14.4.A/LT/2019.

\section{Nomenclature}

$\begin{array}{ll}h & \text { heat transfer coefficient }\left(\mathrm{W} \mathrm{m}-{ }^{2} \mathrm{~K}^{-1}\right) \\ q^{\prime \prime} & \text { heat flux }\left(\mathrm{W} \mathrm{m}^{-2}\right) \\ \Delta T s & \text { superheat wall temperature }\left({ }^{\circ} \mathrm{C}\right) \\ P & \text { Electric Heating Power }(\mathrm{W}) \\ D & \text { Substrate Diameter }(\mathrm{m}) \\ L & \text { Length of Substrate }(\mathrm{m}) \\ V & \text { Voltage of Electric Heater }(\mathrm{V}) \\ I & \text { Electric Heating Flow }(\mathrm{A})\end{array}$

\section{References}

1) N. Putra and W.N. Septiadi, "Heat Pipe Technology: Theory, Design and Application,” Jakarta: UI-PRESS (2014)

2) S.K. Das, N. Putra, and W. Roetzel. "Pool Boiling Characteristics of Nano-Fluids.” International Journal of Heat and Mass Transfer 46: 851-62 (2003). doi:10.1016/S0017-9310(02)00348-4

3) H. Jouhara, A. Chauhan, T. Nannou, S. Almahmoud, B. Delpech, dan L. C. Wrobel. "Heat pipe based systems - Advances and applications,” Energy, vol. 128, hal. 729-754 (2017). doi:10.1016/j.energy.2017.04.028

4) Septiadi, Wayan Nata, I K G Wirawan. "Improved Thermal Performance of Heat Pipe with Hybrid Nanofluid." Conference of National Energy and Manufacturing Industry (SIGER): 7-8 (2017)

5) Wang, Xiang-qi, and Arun $S$ Mujumdar. "Heat Transfer Characteristics of Nanofluids : A Review." International Journal of Thermal Sciences 46: 1-19 (2007). doi: 10.1016/j.ijthermalsci.2006.06.010

6) Nandy Putra, Wayan Nata Septiadi, Haolia Rahman, Ridho Irwansyah. "Thermal performance of screen mesh wick heat pipes with nanofluids." Experimental Thermal and Fluid Science, 40: 10-17 (2012). doi: 10.1016/j.expthermflusci.2012.01.007

7) Nandy Putra, Rosari Saleh, Wayan Nata Septiadi, Ashar Okta, Zein Hamid. "Thermal performance of biomaterial wick loop heat pipes with water-based $\mathrm{Al}_{2} \mathrm{O}_{3}$ nanofluids." International Journal of Thermal Science, 76: 128-136 (2014). doi: 10.1016/j.ijthermalsci.2013.08.020

8) W.N. Septiadi, N. Putra, M. Juarsa, I.P.A Putra, R. Sahmura. "Characteristics of screen mesh wick heat pipe with nano-fluid as passive cooling system."
Atom Indonesia Vol 36 Issue 1: 24-31 (2013)

9) Luh Putu Ike Midiani, Wayan Nata Septiadi, I Nyoman Suprapta Winaya, Made Sucipta, Nandy Putra. "Characterization of capillary pumping amount in novel sintered zeolites and hybrid zeolite-Cu for heat pipe application." International Journal of Heat and Mass Transfer. (2019). doi: 10.1016/j.ijheatmasstransfer.2019.118759

10) Rahman, Haolia. "Experimental Study of Screen Mesh and Sintered Powder Wick on Performance of Heat Pipe.” Universitas Indonesia (2011)

11) W.N. Septiadi and N. Putra, "Boiling Phenomenon of Tabulate Biomaterial Wick Heat Pipe”, Applied Mechanics and Materials, Vol. 776, pp. 289-293 (2015).

doi:

10.4028/www.scientific.net/AMM.776.289

12) N. Putra and W.N. Septiadi, "Improvement of heat pipe performance through integration of a coral biomaterial wick structure into the heat pipe of a CPU cooling system.” Heat Mass Transfer, 53(4), pp.1163-1174 (2017)

13) L.L. Vasiliev, L.P. Grakovich, M.I. Rabetsky, and L.L. Vasiliev Jr. "Heat Transfer Enhancement in Heat Transfers and Thermosyphons Using Nanotechnologies (Nanofluids, Nanocoatings, and Nanocomposites) as an HP Envelope." Heat Pipe Science and Technology, An International Journal, 4(4): 251-275 (2013). doi: 10.1615/HeatPipeScieTech.2014011995

14) A. Brusly Solomon, K. Ramachandran, B.C. Pilai. "Thermal Performance of a heat pipe with nanoparticles coated wick." Applied Thermal Engineering, 36: 106-112 (2012). doi: 10.1016/j.applthermaleng.2011.12.004

15) R. Sureshkumar, S. Tharves Mohideen, N. Nethaji. "Heat transfer characteristics of nanofluids in heat pipes: A review." Renewable and Sustainable Energy Reviews, 20: 397-410 (2013). doi: 10.1016/j.rser.2012.11.044

16) Shuang-Fei Li, Yi-Ying Bao, Ping-yang Wang, Zhenhua Liu. "Effect of nano-structure coating on thermal performance of thermosyphon boiling in microchannels." International Journal of Heat and Mass Transfer 124: 463-474 (2018). doi: 10.1016/j.ijheatmasstransfer.2018.03.071

17) Hashimoto, Mitsuo, Hiroto Kasai, Kazuma Usami, Hiroyuki Ryoson, Kazuaki Yazawa, Justin A. Weibel, and Suresh V. Garimella. "Nano-structured two-phase heat spreader for cooling ultra-high heat flux sources." In 2010 14th International Heat Transfer Conference, pp. 523-533. American Society of Mechanical Engineers (2010). doi: 10.1115/IHTC1422765

18) Sadeghinezhad, Emad et al. "A Comprehensive Review on Graphene Nanofluids : Recent Research, Development and Applications.” Energy Conversion and Management 111: 466-87 (2016). Doi: 
10.1016/j.enconman.2016.01.004

19) Mulya Juarsa, Kiswanta, Edy S., Joko P.W., Ismu H., Puradwi I.W. "Phenomenon of Boiling Heat Transfer Based on Loca and Severe Accidents. "Indonesian Journal of Nuclear Science and Technology. 11: 1-12 (2010)

20) Chen, John C. "Correlation for Boiling Heat Transfer to Saturated Fluids in Convective Flow." I\&EC process design and development 5 (1966). doi: 10.1021/i260019a023

21) Md. Sazzadur Rahman , Tak:eshi Nakagawa, Seigi Mizuno. Germanene: "Experimental Study for Graphene Like Two Dimensional Germanium". EVERGREEN, Journal of Navoel Carbon Resource \& green Asia Strategy, Vol 1 Issue 2 :pp 25-29 (2014)

22) Chavez, A, Milo S P Shaffer, and Aldo R Boccaccini. "Applications of Graphene Electrophoretic Deposition . A Review .” The Journal of Physical Chemistry (2012). Doi: 10.1021/jp3064917

23) Balandin, Alexander A. "Thermal Properties of Graphene, Carbon Nanotubes and Nanostructured Carbon Materials.” : 1-37 (2011)

24) Praswasti P.D.K.Wulan, Juli Ayu Ningtyas, Miranda Hasanah. "The Effect of Nickel Coating on Stainless steel 316 on Growth of Carbon Nanotube from Polypropylene Waste" EVERGREEN, Journal of Navoel Carbon Resource \& green Asia Strategy, Vol 6 Issue 1 :pp 98-102 (2019)

25) Hooman Yarmand, Samira Gharehkhani, Goodarz Ahmadi, Seyed Farid Seyed Shirazi, Saeid Baradaran, Elham Montazer, Mohd Nasrul Mohd Zubir, Maryam Sadat Alehashem, S.N. Kazi, Mahidzal Dahari. "Graphene nanoplatelets-silver hybrid nanofluids for enhanced heat transfer." Energy Conversion and Management $100 \quad$ :419-428 (2015). doi: 10.1016/j.enconman.2015.05.023 